\title{
Determination of Auditory And Visual Learning Styles of Adult Learners in Adult Literacy Centres in Anambra State, Nigeria.
}

\author{
${ }^{1}$ Chieke, J. C. (M.Ed), ${ }^{2}$ Ewelum, J. N. (Ph.D), ${ }^{3}$ Madu, C. O. (Ph.D). \\ Department of Adult Education, Nnamdi Azikiwe University, Awka, Anambra State, Nigeria.
}

\begin{abstract}
The aim of this study is to determine the auditory and visual learning styles of adult learners in Adult Literacy Centres in Anambra State. Two research questions guided. The study adopted descriptive survey. The population of this study was 12,315 adult learners in only government owned adult literacy centres of Anambra state. Purposive sampling technique was used to select 1,607 adult learners for the study. A 14 items questionnaire developed by the researcher, titled, (1) Determination of Auditory learning Style of Adult Learners Questionnaire (DALSALQ) (2) Determination of Visual Learning Style of Adult Learner's Questionnaire (DVLSALQ) were used as instruments for data collection. The questionnaire were validated by experts in Adult Education and Measurement and Evaluation Departments of Nnamdi Azikiwe University, Awka. Data collected was analyzed using mean scores. The Spearman or Rank difference correlation coefficient was used to determine the reliability coefficient of the instruments which stood at 0.88 and 0.82 respectively. Findings of the study show that most adult learners in Anambra state use auditory and visual learning styles in their learning. Based on the findings, this study concludes and recommends that the use of group discussions, power points, illustrated diagrams and pictures, textbooks, radios and tapes recorders should be emphasized in all adult literacy centres in the state.
\end{abstract}

Keywords: Determination, Auditory, Visual, Styles, Adult Learners, Adult Literacy.

\section{Introduction}

Learning styles, by definition, are learning strategies peculiar to an individual which help that individual to learn well. However, Snowwoman and Biechler (2003) believed that learning styles are preferences for dealing with intellectual tasks in a particular way. In addition, Dunn and Dunn (2003) defined learning styles as the way in which each person begins to concentrate, process, and remember new and difficult academic content.

There are many types of learning styles today in literature, such as, emotional, environmental, psychological, sociological and physical learning styles but, Rochester Institute of Technology (2011) classified learning styles of adult learners as auditory, visual, kinesthetic and environmental. For the purpose of this study, the researchers wantto focus on the auditory and visual learning styles of adult learners in Anambra state. This is, because, not too long ago, the government of Anambra state in conjunction with federal government of Nigeria decided to embark on radio literacy for adult learners in the state. Radio literacy falls under the category of auditory learning style. Then, the question is, how many adult learners in Anambra state are auditory learners? How many adult learners, actually, will benefit from this radio literacy programme? This is what this paper seeks to determine. This paper will be of immense benefit to the Anambra state government because it will help the state government to prioritize its educational programmes for adult learners in the state.

Auditory learning style is a learning style in which a person learns through listening. Coffield, Mosdey, Hall and Ecclestone (2004) defined auditory learning style as a process by which individuals learn via listening to tapes, radios and lectures. They went further to say that auditory learners depend on hearing and speaking as their main way of learning. In this vein, Vak (2001) stressed that auditory learners' process information best when it is spoken. Vincent and Ross (2001) opined that auditory learners do best through group discussion and lecture methods. In a work carried out by Bricheno and Younger (2004), they found out that females are more auditory learners than males. Vak (2001) advised auditory learners to read aloud and recite information when learning. He concludes by asserting that auditory learners are story tellers. It is, therefore, necessary to determine the auditory learning style of adult learners in Anambra state so as to know whether the radio literacy programme being carried out by the Anambra state government will be a success or not. On the other hand, visual learning style is a learning style in which learners learn by seeing the object. Rochester Institute of technology (2011) however, defined visual learning style as a learning style in which ideas, concepts, data and other information are processed with images and visual techniques. Rochester went further to state that visual 
learners' process information best when it is visually demonstrated or illustrated. Vak (2001 added that visual learners learn best through seeing, for example, textbooks, demonstration, projects.

According to Vogal, Sary, Dupout and Orban (2002), the visual learning centre is located at the Cortex of the brain. These authors stressed that it is this visual learning field or centre that is responsible for recognizing and categorizing new materials that have entered into the brainfor encoding process, the process which leads to learning. Farkas (2003) maintained that young adult males prefer visual learning style to young adult females.Supporting this view, Bricheno and Yomger (2004) said that males are more visual learners than females. Vak (2001) and Farkas (2003) emphasized that adult learners who use visual learning style remember and recall information or facts faster and better than those who do not use visual learning style. Vak concluded by saying that visual learning style helps its users to achieve better grades in the school.

It is, therefore, important to determine the visual learning style of adult learners in Anambra state so as to help the Anambra state government to plan ahead for visual adult learners in the state. Anambra state consists of 21 local government areas with government owned adult literacy centres scattered all over the local government areas, where adult learners attend their literacy programmes. Adult learners in Anambra state are made up of adult males and females.

\section{Research Questions.}

\section{The following research questions guided the study}

1. Do adult learners prefer auditory learning style to other learning styles?

2. Do adult learners prefer visual learning style to other learning styles?

\section{Methods and Materials.}

This study was a descriptive survey research. The area of the study was the entire Anambra state which consists of 21 local government areas, as follows (see Appendix A). The population of the study was 12,315 adult learners. 1607 adult learners were purposively selected and used for the study. The researcher developed two sets of questionnaire.One wastitled 'Determination of Auditory Learning Style of Adult Learners Questionnaire (DALSALQ)and the other was titled, 'Determination of Visual Learning Style of Adult Learners Questionnaire (DVLSALQ).Both were used as instruments for this study. Both DALSALQ and DVLSALQ have 14 items structured on a 5 point Likert rating scale of Strongly Agree (SA) - 5 points; Agree (A)- 4 points; Undecided (UD)- 3 points; Disagree (D) -2 points; and Strongly Disagree (SD) -1 point.

The instruments were duly validated by three experts in the departments of Adult Education and Measurement and Evaluation of Nnamdi Azikiwe University, Awka. Using the Spearman's Rank Order correlation coefficient, the reliability coefficient of both DALSALQ and DVLSALQ were determined, which yielded 0.88 and 0.82 respectively. Data collected were analyzed with mean. A mean score of 3.00 and above were regarded as auditory learning style or visual learning style as the case may be while mean scores below 3.00 werenot regarded as auditory learning style or visual learning style.

\section{Results}

Table 1: mean scores of adult learners on their preference of auditory learning style

\begin{tabular}{|l|l|l|l|}
\hline S/N & Items & $\bar{X}$ & Remarks \\
\hline 1 & I learn best via discussion & 4.52 & Agreed \\
\hline 2 & I learn best with experimentation & 2.92 & Disagreed \\
\hline 3 & I prefer touching and examination of objects & 2.41 & Disagreed \\
\hline 4 & I prefer lecture method & 3.80 & Agreed \\
\hline 5 & I prefer learning under dim light & 2.67 & Disagreed \\
\hline 6 & I prefer group learning & 3.01 & Agreed \\
\hline 7 & I prefer going on excursion & 2.35 & Disagreed \\
\hline 8 & I learn best via tapes & 3.76 & Agreed \\
\hline 9 & I learn best when I am well fed & 1.96 & Disagreed \\
\hline 10 & I prefer listening to radio programmes & 4.28 & Agreed \\
\hline 11 & I learn best when taking notes & 2.55 & Disagreed \\
\hline 12 & I prefer lecture method & 3.24 & Agreed \\
\hline 13 & I learn best when dictated to & 3.00 & Agreed \\
\hline 14 & I prefer cool room & 2.11 & Disagreed \\
\hline
\end{tabular}

Table 1 shows that adult learners in Anambra state agreed with all the items on auditory learning style as their preferred learning style. They include items a 1,4,6,8,10,12, and 13. Nonetheless, the learners disagreed with other items. This shows that most adult learners in the state are auditory learners. 
Table 2: Mean scores of adult learners on their preference of visual learning style.

\begin{tabular}{|l|l|l|l|}
\hline S/N & Items & $\bar{X}$ & Remarks \\
\hline 1 & I learn best with textbooks & 4.75 & Agreed \\
\hline 2 & I prefer writing on the board & 3.01 & Agreed \\
\hline 3 & I learnt best at night & 2.82 & Disagreed \\
\hline 4 & I can study at any time of the day & 2.02 & Disagreed \\
\hline 5 & I prefer morning study & 3.00 & Agreed \\
\hline 6 & I learn best with demonstration & 3.65 & Agreed \\
\hline 7 & $\begin{array}{l}\text { I prefer learning with illustrated } \\
\text { diagrams, pictures }\end{array}$ & 4.52 & Agreed \\
\hline 8 & I prefer dim light & 2.58 & Disagreed \\
\hline 9 & I prefer bright light & 2.95 & Disagreed \\
\hline 10 & I learn best with handouts & 3.22 & Agreed \\
\hline 11 & $\begin{array}{l}\text { I prefer learning with power point, } \\
\text { projectors }\end{array}$ & 4.34 & Agreed \\
\hline 12 & I learn better via excursion & 1.77 & Disagreed \\
\hline 13 & $\begin{array}{l}\text { I understand better seeing instructor's } \\
\text { body movement }\end{array}$ & 2.45 & Disagreed \\
\hline 14 & I learn best via television & 3.00 & Agreed \\
\hline
\end{tabular}

Table 2 shows that adult learner in Anambra state agreed with all the items on visual learning style except item 13 (which is seeing instructor's body movement) as their preferred learning style. The items include $1,2,5,6,7,10,11$ and 14. Nevertheless, the learners disagreed with other items. This equally demonstrates that adult learners in Anambra state are visual learners.

\section{Discussion}

The result of the study in table 1 shows that learning which includes discussion listening to radio programmes, lectures, among others is the best way adult learners in Anambra State learn. This is in line with Vincent and Ross (2001) who said that auditory learners process information best when it is spoken, for example, through lectures, group discussion and listening to tapes. This also agrees with Coffield, Moseley, Hall and Ecclestone (2004) who believed that adult learners do well through listening to radios and tapes. Learning according to one's style gives one satisfaction. This is in line with Sadker and Sadker (2003) who stressed that learning according to one's learning style leads to learning efficiency and effectiveness.

In the same vein, the results in table 2 shows that some learners learn best through visual learning style which includes learning with textbooks, diagrams and pictures. This is in agreement with Vak (2001) who said that adult learners process information best through reading textbooks. It equally tandem with Rochester Institute of technology (2011) which stated that adult learners lean best with illustrated diagrams and pictures and Chieke (2015) who affirmed that poor use of instructional materials in adult literacy centres in Anambra state affects adult learning. Finally, the findings from this work show that most adult learners in the state are audio-visual learners. They learn best through seeing and listening.

\section{Conclusion}

It can be deduced from the foregoing that learning according to one's learning style cannot be underestimated. This is because adult learners develop learning styles overtime since they are self-directed and independent. Auditory and visual learners do better in theirprogramme when they are provided with their preferred learning styles in conducive environment. These include learning via tapes, radios and lectures by auditory learners and learning by seeing object and images by visual learners. Learning can also be meaningful if professional adult educators are recruited to handle instructional delivery of the course contents.

\section{Recommendations}

\section{Based on the findings, the following recommendations were made:}

1. The government of Anambra state should encourage group discussion in adult literacy centres in the state so that adult learners will maximize their learning.

2. The government of Anambra state should make available, radios and tape recorders for adult learners in all the adult literacy centres in the state. This will serve as a motivation and incentives for the learners.

3. Adult instructors in the state should be encouraged to read education courses, especially adult education in Nigerian universities and abroad, so as to help them master the arts and science of helping adults learn. 
4. Power point and projectors should be instituted in all adult literacy centres in Anambra state to aid learning. It will equally help learners acquire power point skills in presenting their assignments and projects.

5. Utilization of the available instructional materials in adult literacy centres in the State should be enforced. This will help to concretize learning.

\section{References}

[1]. Bricheno, P. \& Yomger, M. (2004). Use of learning styles. Retrieved on $9^{\text {th }}$ August, 2004 from www.standarddfes.govts:Uk/thinking skills/resources.

[2]. Chieke, J. C. (2014). Determination of preferred learning styles of adult learners as ameans of enhancing their academic performance in adult literacy centres in Anambra state. Unpublished thesis Nnamdi Azikiwe University, Awka.

[3]. Chieke, J. C. (2015) "Constraints on the effective implementation of adult education programmes and the way forward in Otuocha Educational zone of Anambra state" The International Journal of Educational Research and Development. 5, (10), 59-65.

[4]. Coffield, F., Moseley, D., Hall, E. \& Ecclestone, K. (2004). Learning style and pedagogy in post 16 learning; A systematic and critical review. London: learning and skill research centre.

[5]. Dunn, R \& Dunn, K. (2003). Epilogue so what? In R. Dunn \& S. Griggs (eds). Synthesis of the Dunn and Dunn learning styles model. New York: St. John's University Press.

[6]. Farkas, R. (2003) "Effects of traditional versus learning styles instructional methods on middle school students". The Journal of education research 97; (1), 42-51.

[7]. Quellette, R. (2000) Learning styles in adult education: from http://pelaris.umuc.edu/quellette/learning styles/htm.retrieved July 24, 2011.

[8]. Rochester Institute of technology (2011). Characteristics of adult learners. Retrieved 5/3/2011. http://onlineriteedu/faculty/teaching-strategies/adultlearners. com

[9]. Sadker, M. P. \& Sadker, D. M. (2003). Teachers, school and society. New York: McGraw Hill Company Inc.

[10]. Snowman, J. \& Biechler, R (2003). Psychology applied to teaching. $10^{\text {th }}$ edition. USA: Houghton Mifflin Company.

[11]. Vak, K. (2001) Vak model of learning styles. Retrieved September 14, 2012. From; http://Vak-learn.com/english/index.asp

[12]. Viegel, R., Sary, G., Dupout, P., Orban, G. (2004) Human brain regions involved in visual categorizations. USA; Elservier Science.

[13]. Vincent, A. \& Ross, O. (2001) "Learning Style awareness" Journal of research on Computing in education33,(1): 1-10. 